\title{
MUSICAL COMMUNICATION AND EPIDEMIC: THE ROLE OF MUSIC IN THE COVID- 19 EPIDEMIC
}

\author{
Nural İmik Tanyıldızı ${ }^{1 *}$ \\ * Associate Professor Dr. Firat University, Faculty of Communication, Department of Public Relations and \\ Publicity, Elazığ/Turkey
}

\begin{abstract}
Since ancient times, there has been a lot of information that music has deeply affected the human psyche. It is seen that music is the food of the human psyche and is used even in the treatment process of some diseases. It also includes a communication process in music. The messages given by musical communication have different effects on the target audience. COVID-19 disease, which started at the end of 2019 and spread all over the world in a short time, has affected people in many areas. One of the areas most affected by COVID19 is human psychology. In this study, the effects of musical communication on the human psyche during the COVID-19 process were examined. Qualitative research method was used in this study. Semi-structured interview technique was used in the research. For this purpose, pre-prepared interview questions were asked to 30 people through online interviews. The obtained data were recorded by the researcher. The data were analyzed by the qualitative research method. It has been trying to determine how music affects the human psyche during the pandemic process.
\end{abstract}

Keywords: Music, musical communication, COVID-19, human psyche.

\section{SALGIN VE MÜZiKSEL ILETişiM: COVID-19 SALGININDA MÜZiĞiN ROLÜ}

\section{Özet}

Eski çağlardan beri müziğin insan ruhunu derinden etkilediğine yönelik birçok bilgiye ulaşılmaktadır. Müziğin insan ruhunun gıdası olduğu ve bazı hastalıkların tedavi sürecinde bile kullanıldığı görülmektedir. Müzik içerisinde aynı zamanda bir iletişim sürecini barındırmaktadır. Müziksel iletişim ile verilen mesajlar hedef kitleler üzerinde farklı etkiler yapmaktadır. 2019 yılının sonunda başlayan ve kısa surede tüm dünyaya yayılan COVID-19 hastalığı insanları birçok alanda etkilemiştir. COVID-19'un en çok etkilediği alanlardan biri de insan psikolojisidir. Bu çalışmada COVID-19 sürecinde müziksel iletişimin insan ruhuna etkileri incelenmiştir. Bu çalışmada nitel araştırma yöntemi kullanılmıştır. Araştırmada yarı yapılandırımış görüşme tekniği uygulanmıştır. Bu amaçla 30 kişiye önceden hazırlanmış mülakat soruları çevrimiçi görüşme ile sorulmuştur. Elde edilen veriler araştırmacı tarafından kayıt altına alınmışır. Veriler nitel araştırma yöntemi ile analiz edilmiştir. Pandemi sürecinde müziğin insan ruhunu nasıl etkilediği belirlenmeye çalışımıştır.

Anahtar Kelimler: Müzik, müziksel iletişim, COVID-19, insan ruhu.

\section{Introduction}

Music is one of the most important forms of communication that deeply affect the human psyche. Music is both a form of communication and a communication tool. "Music is a universal form of human communication capable of overcoming linguistic, physical, mental and cognitive barriers to understanding with others "(Wigram and Elefant, 2009: 442, Cross, 2014: 2). In addition, most of the experimental studies on music from the cognitive sciences perspective have treated music as a manifestation of patterns in sound. They discovered the music as heard (Cross, 2012). There are three important stages of musical communication in history. The first of these is the use of notes, namely music writing. The second is "note printing", which enables the reproduction of musical writing and the transmission of notes to a large number of musicians. The third is technological inventions such as radio that record sounds and transmit them to large masses (Say, 2008: 16).

Music is a one form of art. The musicians symbolize the intended messages and codify them and allow the spectator or viewer to decode and interpret the hidden messages or meanings (Sharma, 2013:1). Music as a form of communication; It is a tool by which people express their individual and social identities and express

1Sorumlu Yazar email: nimik@firat.edu.tr / Doi: 10.22252/ijca.830041 
themselves through the emotions they make (Hargreavers, North, 1999: 79; Özdemir, 2014: 40). Especially songs can convey many emotions that people cannot express. The songs are one of the art forms closer to the public. It has traditionally been a tool that people use to convey their feelings and thoughts with others, without leaving a printed record behind (Lull 2000: 51; Tanyıldızı, 2012: 103) There is a certain communication system in music. In it, direct sensuality nourishes the true artistic message as an emotional fuel. Music has invaluable potential in terms of different pitches and durations, colors and sound intensity. The infinite potentials of sequential and simultaneous combinations are suitable for constructing audible, dynamic models of human relationships and types of behavior, internal events and interactions, different situations (Ujfalussy, 1993: 7).

Music has a powerful effect on people. Because music affects the brain, which is the center of human sensory and conscious behavior. People didn't just communicate with music. In addition, they used music as an auxiliary tool to solve their psychological problems. Thus, the therapeutic effects of music emerged (Özçevik, 2007: 1). The method of spiritual healing with music started in Central Asian Turkish Culture in ancient times. It has been applied by people with versatile tasks. It is also applied today (SomakcI, 2003: 137). There is general consensus that music is both universal and communicative. Musical dialogue plays a key role in most musictherapeutic applications. However, the idea that music is a communicative medium has received little attention within the cognitive sciences to date. Limited research into how and what music transmits has resulted in findings that appear to be of limited relevance to music therapy (Cross, 2014:1). In the literature research, many scientific studies have been reached that address the therapeutic aspect of music psychology (Goldman, 1988; De Backer and Wigram, 1993; Hargreaves and North 1999; Robb, 2000; Thram, 2002; Somakcl, 2003; Özçevik, 2007; Aldridge and Aldridge, 2008; Arslan, 2015, Silverman, 2019). Turkish people attach importance to sincerity and sincerity in communication processes. With COVID-19, it is a process where social and physical isolation is at the forefront. This situation causes individuals to be affected psychologically (Deniz, 2020: 203). In this study, it was aimed to reveal how musical communication affects the human psyche in the pandemic process. During COVID-19, it was trying to explain how music affects the listeners. Qualitative method has been used. Questions were directed to people through online interviews. The obtained data were analyzed. This research is important in terms of examining the effect of musical communication on the human psyche during the pandemic period.

\subsection{Effects of Musical Communication on the Human Psyche}

The effects of music on people are divided into psychological effects and physical effects. Analyzing the physiological and psychological effects of music is very difficult. There are two theories here. One of these is the primary effect music has on emotions. The second of these is the psychological effect caused by the physiological effects of music (Gençel, 2006: 702). It is possible to say that music affects the human psyche both when it is produced and transmitted to the target audience.

Art and music have served as a visual and audio media for symbolic mass communication for thousands of years. Studies in recent years say that music affects the nervous system. It is known that an artist's production of music enriches the culture and art of human society from the past to the present (Azizi, 2009: 1-2; Boşnak et al., 2017: 35). Music, in short, is the art of expressing emotions, thoughts and symbols in monophonic or polyphonic forms. In other words, music is the transmission of spoken language, which is the basic way of expressing, in another form (Kutlay, 2007: 10). Music is universal and communicative. This view is prevalent not only in the field of music therapy, but also in the broader field of writing and thought about music (Cross, 2014: 2).

Arranged in a meaningful sequence, musical works can reach the oldest unconscious depths of the human psyche and the highest personalities of human existence. Music occupies man as a whole. Music fundamentals take you straight to the heart of your listeners (Perlovsky, 2005: 7). Music has an effect that will even speed up the flow of blood. With music, it is possible to quench a person's sadness or to turn him into pessimism by affecting them to the point of going crazy (Colombe, 2006: 90; Arslan, 2015: 107). When we listen to music that suits our mood, we keep pace with the sound environment without realizing it. Such music is better than silence, especially for people in pain, because silence leads to more awareness of the disturbance. Pace describes how brain waves, heart rhythm, breathing, emotional strength, timing, pace, and other organic rhythms change according to the music we listen to. Also, listening to music helps relieve stress and relax. Music can act as a powerful accelerator in the healing process (Boşnak et al, 2017: 41).

Music really started with the evolution of the human ear and vocal organs. In fact, it has been inherited in our minds from the very beginning as an innate rhythm in our body. That's why we act spontaneously if we listen 
to music. Music connects us to a harmonious, rhythmic and universal spirit (Sharma, 2013: 2). Music has effects such as opening the mind, improving the imagination, creating excitement, stimulating love, encouraging and hoping. Sometimes the background music used to cover up noise can have a relaxing effect. Or background music in stores can stimulate the customers' sense of shopping (Arslan, 2015: 111).

Different music can affect people in different ways. For example, melody is one of the aspects related to the nature of music, and it is difficult to decide exactly why one melody is so attractive to us over another. Melody can move us. It can almost envelop me. According to some composers, melody is the basic essence of music (Aldridge and Aldridge, 2008:10). Panksepp and Bernatzky conducted an experiment on 16 university students to investigate the effects of music on mood. The subjects listened to music in two separate sessions: 40 minutes of cheerful music in the first session and 40 minutes of sad music in the second. While a cheerful style of music creates positive effects on the mood, sad music strengthens negative emotions and weakens positive emotions. Another striking point is that both types of music reduce feelings of anxiety and anger equally. This effect is greatest especially when one does not listen to music (Kutlay, 2007: 24-26). It can be said that musical stimuli have positive effects when used correctly on people. On the contrary, music can have negative effects on people (Sezer, 2011: 1477). When this effect of music on the human psyche is used correctly, it can positively affect the human psyche. Therefore, the effect of musical communication on the human psyche is inevitable.

\subsection{Music in the COVID-19 Process}

The COVID-19 pandemic, which started at the end of 2019 and spread to almost every part of the world in 2020 , has occurred at a time when the human race is more connected than ever. While the spread of the disease on the planet has been accelerated through travel, the sharing of information, views and thoughts about the disease has accelerated with the electronic connection (Tanyıldızı, 2020: 1). In general, pandemics are not just a serious public health problem, but rather trigger disastrous socio-economic and political crises in infected countries. In addition to being the biggest threat to global public health of the century, COVID-19 is recognized as an indicator of inequality and lack of social progress (Chakraborty and Maity, 2020: 2). Pandemics and similar disasters don't only pose a health threat to people, but also affect people socially and psychologically. Anxiety, panic, uncertainty and risk; creates an individual, social and universal culture of fear (Yıldırım, 2020: 1333).

Music is generally perceived as a means of entertainment, according to popular understanding. However, music is an art that expresses feelings and thoughts with sounds or expresses the sounds in order and aesthetics. It is clear that music is not just an entertainment tool with this feature. Music is a concept that reflects the spirit, emotion and thought world of the human being (Gençel, 2006: 701). Music helps us to embody the meaning of life. The beautiful and sublime, art and religious experience, emotions that embody the meaning of life, as well as the highest spiritual experiences are all embodied through music (Perlovsky, 2015: 3).

Throughout history, music has been used for therapeutic purposes to influence the human psyche. In ancient times, the study of using sound and music as a therapeutic tool was a lifelong work with specific private schools devoted to sacred sound and music science, such as the Pvthagoras School in Crotona. It was said that there are three levels of study and initiation at this school. First level students learned the features of musical intervals and acoustics. Second-level scientists worked with mathematics and purification. Students' beginning to learn about the use of sound and music as therapeutic tools was the third and highest level of work gained after years of study and discipline (Goldman, 1988: 30). Again in the Ottoman Empire, music has been used as a means of treatment for centuries (Somakcı, 2003; Sezer and Atıcı, 2010). Music is a therapeutic tool. In this respect, it can be one of the best tools we can use for a true holistic integrity and health model. Music can heal the human body physically and spiritually (Goldman, 1988: 29). Music therapists have often emphasized the role of music in developing therapeutic alliances when treating adults in mental health settings (Silverman, 2019).

It is possible to benefit from this therapeutic effect of music and its power to affect human psychology during the COVID-19 process. During the pandemic period, many musicians started to give digital concerts to boost people's morale. Social media were used in most of these concerts. In the early stages of social lockdown in Europe, musicians quickly moved into the virtual space. Online live streams are a vital remedy for artists and viewers. A clear example of this process can be seen during the "balcony concerts" that took place in Europe 
(especially in Italy) in the early stages of social lockdown. One of the most important features of live streams is that they happen at the same time for all viewers. Thus, feelings of solidarity in people were preserved. It is possible to say that there is a psychological impact on social lockdown (Vandenberg et al., 2020:2-9). During the pandemic, individuals organize online concerts on Instagram to support each other psychologically in Turkey. When famous artists started to accompany the online concert activities of individuals, Instagram started to become a platform where online concerts take place .Individuals can participate in online concerts performed by famous artists from where they are on social media platforms without paying any fee and have the opportunity to communicate with them (Deniz, 2020: 199-200). The curfews imposed with the COVID-19 epidemic also brought mini concerts from the balcony or online into our lives. In particular, Italy, France, Argentina (Euronews, 2020) and Turkey it is possible to give many examples. During the times when there was a need to stay at home during the COVID-19 process, musicians tried to reach people over the internet or through street concerts. People continued to listen to music directly or through various communication tools.

\section{Methodology}

This study has been done by taking scientific methods and techniques into consideration. Information about the purpose, method and sample of the study are given in the following sub-headings.

\subsection{Purpose of the research}

Music is one of the most important food of the human psyche. People encounter music in their daily lives, whether they want to or not. Music includes a communication process both while creating and delivering it to the target audience. The purpose of this research is to reveal how musical communication affects the human psyche during the COVID-19 pandemic process.

\subsection{Research Hypothesis}

The hypothesis of this research is: "The communication established through music during the COVID-19 process has a positive effect on the human psyche. Music can be used to positively affect people psychologically during pandemic processes".

\subsection{Research Method}

This research has been done with the qualitative research method. Semi-structured interviews were applied to 30 people determined in the study. Some of the questions are open ended and some are closed. Qualitative research is done to understand the complex nature of reality. It is the interpretation of the subjective representation of the big picture that people perceive with symbols (Kümbetoğlu, 2012: 24). Qualitative data collection methods such as observation, interview and document analysis are used in qualitative research (Yıldırım and Şimşek, 2018: 41). One of the commonly used data collection techniques in research is interviewed. Interviews are a purposeful conversation in which pre-prepared questions are asked and the other person answers the questions (Kuş, 2003, 50). Interview technique is one of the most used and most basic data collection techniques in qualitative research. There are varieties such as semi-structured, unstructured, in-depth, and oral history. It is a flexible method that allows the participant to express their personal experiences, perspective and thoughts on a subject in their own words (Tüsside Tübitak, 2020). It is done to introduce some aspects of people or to enlighten a subject. Some questions were standardized in the semistructured interview, and some questions were prepared as open-ended. In this type of interview, it is possible to obtain in-depth information (Güldü, 2020). Interviews can be done face-to-face or by phone with remote people (Bailey, 1987:185-204). It can be used in conversation in other technological devices today (Yıldırım and Şimşek, 2018). In the study, interview questions were applied online to 30 people. While applying the questions, they were impartial and clear. The questions asked in the research are listed below:

- Do you like listening to music?

- What is your favorite type of music?

- Do you think music has a communicative dimension? Why does it exist or why not?

- Did you increase your time of listening to music during the Covid-19 process? 
- Which tool do you use more while listening to music during the pandemic process?

- Do you think music can affect the human psyche during the pandemic process?

- How does music affect your psyche during the pandemic process?

- Do you usually listen to music alone or with family members during the pandemic process?

- Do you think music has a positive or negative effect on the human psyche during the pandemic period?

The answers given to the questions were recorded. Individual answers were examined systematically. The data obtained were written, analyzed and interpreted.

\subsection{Study Population and Sample}

The universe of the study consists of people over the age of 18 , university graduates. The researcher first reached two people in his immediate vicinity. Later, other people were reached through them. In this study, 30 people were interviewed using the snowball sampling technique. The people participating in the study are between 18 and 60 years old. It was stated that the thoughts of the people participating in the study will be used in an academic study. The interviews were recorded with the permission of the participants.

\section{Analyzing and Interpreting Findings}

12 of the participants were men and 18 people were women. The youngest of the participants was 23 years old and the oldest was 57 years old.

First, the participants were asked "Do you like listening to music? The question has been posed. All of the participants answered "yes" to this question.

Interview questions were asked to individuals through online interviews. The data obtained was recorded. The data obtained as a result of the qualitative analysis were shown in tables. Since the answers given to some open-ended questions were multiple choices, the table was not used. The findings obtained as a result of the analysis were given below:

Table 1. Favorite music style of the participants

\begin{tabular}{|l|l|}
\hline Turkish Folk Music & 4 \\
\hline Turkish Art Music & 3 \\
\hline Turkish Pop Music & 6 \\
\hline Rap Music & 2 \\
\hline Rock Music & 3 \\
\hline Classic Music & 4 \\
\hline Instrumental Music & 2 \\
\hline Jazz & 1 \\
\hline Foreign Pop & 4 \\
\hline Hip Hop & 1 \\
\hline Total & 30 \\
\hline
\end{tabular}

Secondly, the participants were asked about their favorite style of music. Participants' favorite music style is Turkish Pop. Apart from that, the most popular music styles are Turkish Folk Music, Classical Music and Foreign Pop. In general, we can say that the participants like to listen to pop music the most.

The third question of the research: "Do you think music has a communicative dimension? Why is there or why not? 30 participants gave a positive answer to this question. He said that music has a communicative dimension. Why is there a communicative dimension in music? Some of the answers given to the question are below:

- "I think music is a very powerful communication tool. It can be seen as a universal communication tool, as it can give a message with its melody as well as its lyrics. The fact that the artist can convey his feelings and thoughts to everyone who listens is also powerful because he can give people that feeling while doing this. "(Man, 23 years old)

- $\quad$ "Because music can convey a feeling in any language." (Woman, 35)

- $\quad$ "Because music is universal" (Man, 48)

- "Absolutely. Because music is the easiest way to express emotions. "(Woman, 27) 
- "I think there is. Because music expresses our thoughts and feelings that we sometimes cannot express. We can express ourselves with music and share with our friends about that music "(Woman, 42)

- $\quad$ "Because we find our own lyrics in every song." (Man, 43)

- "Music has a communication dimension. Music is the translator of people's emotions and I can express my feelings to the other party through music. "(Woman, 38)

- "Music has a communicative dimension. Creates a story in a person, takes the person to a time and place. "(Woman, 50)

- "I think the communication aspect of music is extremely important. Because music is universal. Regardless of the language of the music, you can communicate as much as you feel. (Man, 37)

- $\quad$ "There is. Music is the expression of feelings and thoughts. "(Man, 52)

- $\quad$ "Absolutely. I think everyone has a common language on a universal scale. For music, it can be said that it is the most effective way to reflect a common language in expression, starting from the acceptance of social stability, since emotions express common human values. " (Woman, 29)

- $\quad$ "Of course there is. It strengthens communication between people, it can gather and separate people around common feelings and thoughts as a whole. "(Man, 34).

$100 \%$ of the participants agreed that music is a communication dimension. When looking at the answers given, it is generally said that music is the universal language that conveys feelings and thoughts. Therefore, it is accepted that music has a communicative dimension. In addition, it is stated that music takes the listeners to a certain time and place and facilitates self-expression.

Table 2. Whether there was an increase in the time to listen to music during the COVID-19 process

\begin{tabular}{|l|l|l|}
\hline & Woman & Man \\
\hline Yes the time has increased & 16 & 9 \\
\hline No time didn't increase & 2 & 3 \\
\hline Total & & 30 \\
\hline
\end{tabular}

Table 2 shows the times of music listening during the COVID-19 process. The duration of listening to music for 5 people participating in the study did not change. 25 people, on the other hand, increased the time for listening to music. The music listening process about $83.3 \%$ of the participants has increased. In this case, it is possible to say that people's listening time increased during the COVID-19 process.

Table 3.In which mass media the participants listen to music the most during the COVID-19 process

\begin{tabular}{|l|l|}
\hline Mass media used to listen to music & \\
\hline Radio & 2 \\
\hline Television & 1 \\
\hline Mobile phone & 17 \\
\hline Computer & 10 \\
\hline Total & 30 \\
\hline
\end{tabular}

Table 3 showed from which media the music was listened to during the pandemic period. 17 of the people participating in the research, listened to music from the phone and 10 people from the computer. People listening on computers and phones stated that they used an internet-based social networks such as YouTube. According to these data, $90 \%$ of the participants in the research, listened to music over the internet.

Table 4. Whether listening to music has an impact on the human psyche during COVID-19 process

\begin{tabular}{|l|l|l|}
\hline & Woman & Man \\
\hline Yes & 18 & 10 \\
\hline No & - & 2 \\
\hline Total & & 30 \\
\hline
\end{tabular}

The 6th question of the research was whether listening to music has an effect on the human psyche during the pandemic process. $93.3 \%$ of the participants said that music affected the human psyche during the pandemic process. It has seemed that music affects the human psyche in the process of COVID-19.

Table 5.How listening to music affects the human psyche during COVID-19

\begin{tabular}{|l|l|}
\hline Effects of music on the human psyche & \\
\hline It reduces my anxiety & 6 \\
\hline
\end{tabular}




\begin{tabular}{|l|l|}
\hline Calms down & 4 \\
\hline Makes me forget the problems & 3 \\
\hline Entertains & 3 \\
\hline Brings back memories & 5 \\
\hline It takes my tension down & 2 \\
\hline Makes you feel happy & 5 \\
\hline It has no effect & 2 \\
\hline Total & 30 \\
\hline
\end{tabular}

The 7th question of the research was about how music affects the psyche during the pandemic process. The answers given by the participants to this question were that it reduces anxiety, makes you feel happy, and revitalizes memories, calms, makes you forget the problems, entertain them and reduce tension. In addition to these answers, most of the respondents stated that these feelings were mostly related to the type of music listened to. They said that the effect of slow or moving music on the human psyche is different. In addition, it is stated in the lyrics that music shapes the effect on the human psyche. Only 2 people stated that music had no effect on them. It can be said that there is a relationship between the types of music listened to during the COVID-19 process, the lyrics and how the music affects the human psyche.

Table 6.With whom they listened to music during the COVID-19 process

\begin{tabular}{|l|l|}
\hline & \\
\hline Alone & 21 \\
\hline With family & 6 \\
\hline With friend & 3 \\
\hline Total & 30 \\
\hline
\end{tabular}

Question 8 was to measure whether the participants are alone in the musical interaction process. According to the data, $70 \%$ of the participants listened to music alone during the COVID-19 process. Apart from this, the participants listened to music with their family or friends. Based on these data, it is possible to say that people who were alone during the COVID19 process listened to music more.

Table 7.Whether music has a positive effect on the human psyche during the COVID-19 process

\begin{tabular}{|l|l|l|}
\hline & Woman & Man \\
\hline Positive & 18 & 10 \\
\hline Negative & - & - \\
\hline Neutral & - & 2 \\
\hline Total & & 30 \\
\hline
\end{tabular}

Finally, the participants were asked whether the effect of music on the human psyche was positive during the pandemic process. $100 \%$ of the female participants stated that music has a positive effect. $84.6 \%$ of the male participants gave a positive answer. According to the participants, listening to music has a positive effect on the human psyche during the COVID-19 process.

\section{Conclusion}

During the COVID-19 pandemic, online or street concerts have increased around the world. It is possible to say that people's need for music increased, especially in times of curfews. In this study, interview questions were asked about the effects of musical communication on the human psyche during the COVID-19 process. Findings obtained from these questions were analyzed. The results obtained from this research are given below:

- $100 \%$ of the participants agreed that music is the communication dimension. Music is a powerful communication tool. Music has a communicative dimension. Because music conveys our feelings and thoughts. Also, music is a universal language that unites people in common points.

- $\quad$ During the COVID-19 process, people's time to listen to music has increased

- During the COVID-19 process, people generally listened to music from cell phones and computers. It is connected to the internet to listen to music from these tools.

- According to the participants, music affected the human psyche during the COVID-19 process. During the pandemic process, music helped to reduce anxiety, made you feel happy, stimulated memories, calm 
down, and made you forget problems, entertain and reduce tension. It affected the human psyche with these aspects.

- Most of the participants stated that the effects of music on the psyche are mostly related to the type of music listened to. It is said that whether the music is moving or slow has a different effect on people's psyche. It can be said that there is a relationship between the types of music listened to during the COVID19 process and how it affects the human psyche.

- $\quad$ During the COVID-19 process, people usually have listened to music while alone.

- Regardless of the style of music, according to the participants, listening to music has a positive effect on the human psyche during the COVID-19 process.

- If a general assessment is made, listening to music has had a positive effect on the human psyche during the COVID-19 process. During pandemic processes, musical communication can purify the human psyche from anxiety and worries, calm and relieve tension. It entertains people by making them happy. It can bring your memories back to life. It is thought that the use of musical communication contributes to reducing the negative effects of the pandemic on the human psyche.

\section{References}

Aldridge, D., Aldridge, G. (2008). Melody in music therapy: A therapeutic narrative analysis. Jessica Kingsley Publishers.

Arslan, H. (2015). "Müzik Terapi ve Dini Müzik. Hikmet Yurdu Düşünce-Yorum" Sosyal Bilimler Araştırma Dergisi, Volume: 8(16), p. 103-127.

Azizi SA. (2009). Brain to music to brain! Neuroscience Letters, 459, p. 1-2.

Bailey, D.K. (1987).Methods of Social Research. NewYork: The Free Press.

Boşnak, M., Kurt, A. H., , Yaman, S. (2017). Beynimizin müzik fizyolojisi. Kahramanmaraş Sütçü İmam Üniversitesi Tıp Fakültesi Dergisi, 12(1), p.35-44.

Chakraborty, I., Maity, P. (2020). "COVID-19 outbreak: Migration, effects on society, global environment and prevention". Science of the Total Environment, 138882.

Colombe, C. (2006). "Müziğin İnsan ve Hayvanlara Etkisi", Çev: M. Refik, Ötüken Yay., İstanbul (Osmanlı Türkçesinden sadeleştiren. Prof. M. Salih Ergan, Ahmet Şahin Ak)

Cross, I. (2012). "Cognitive Science and the Cultural Nature of Music". Topics in Cognitive Science, Volume: $4(4)$, p. 668-677.

Cross, I. (2014). "Music and communication in music psychology". Psychology of Music, Volume:42(6), p. 809819.

De Backer, J., , Wigram, T. (1993). "Containment in music therapy". Music therapy in health and education, p. 32-39.

Deniz, A. K. (2020). "Covid-19 Salgını Sürecinde Dijitalleşen Eğlence Anlayışı: Çevrim İçi Konserler”. Stratejik ve Sosyal Araştırmalar Dergisi, Sayı 4(2), p. 191-206.

Euronews (2020). "Covid-19 krizine müzikle direniş: Çevrimiçi ve balkon konserleri", https://tr.euronews.com/2020/04/14/covid-19-krizine-muzikle-direnis-cevrimici-ve-balkon-konserleri.

(25.10.2020).

Gençel, Ö. (2006). “Müzikle tedavi”. Kastamonu Eğitim Dergisi, Volume:14 No:2 , p. 697-706.

Goldman, J. S. (1988). "Toward a new consciousness of the sonic healing arts: The therapeutic use of sound and music for personal and planetary health and transformation". Music therapy, Volume: 7(1), p. 28-33.

Güldü,Ö.(2020)."Araştırma

Yöntem

ve

Teknikleri".

https://acikders.ankara.edu.tr/pluginfile.php/107027/mod resource/content/1/KONU\%209.pdf. (21.10.2020).

Hargreaves, D. J., , North, A. C. (1999). T"he functions of music in everyday life: Redefining the social in music psychology". Psychology of music, Volume: 27(1), p. 71-83. 
Kuş, E. (2003). Sosyal Bilimlerde Araştırma Teknikleri Nitel mi, Nicel mi? Ankara: Anı Publications.

Kutlay, E. B. (2007). Müziğin Bir Pazarlama Elementi Olarak Tüketici Üzerinde Duygusal, Algısal Ve Davranışsal Etkileri, Istanbul University Institute of Social Sciences, Department of Musicology, Unpublished PhD Thesis.

Lull J. (2000). Popüler Müzik ve İletişim, İstanbul: Çiviyazıları.

Kümbetoğlu, B. (2012). Sosyolojide ve antropolojide niteliksel yöntem ve araştırma. İstanbul: Bağlam Publications.

Özçevik, A. (2007). Müzikle Tedavi ve Öğrenciler Üzerindeki Terapik Etkileri, Doctoral dissertation, Istanbul Technical University Institute of Social Sciences.

Özdemir, Ö. (2014). İletişim Aracı Ve Kültür Ürünü Olarak Müzik: Elektronik Dans Müzik Örneği, Published Master Thesis, Kocaeli University, Institute of Social Sciences.

Perlovsky, L. I. (2005). "Music-The First Principle. Role of Music in Evolution of Consciousness,,Musical Theater", E-journal, p. 1-36.

Perlovsky, L. (2015). Origin of music and embodied cognition. Frontiers in Psychology, Volume:6, p.1-4.

Robb, S. L. (2000). The effect of therapeutic music interventions on the behavior of hospitalized children in isolation: Developing a contextual support model of music therapy. Journal of music therapy, Volume:37(2), p. 118-146.

Say A. (2008). Müzik Nedir, Nasıl Bir Sanattır, İstanbul: Evrensel Publication.

Sezer, E., Atıcı, E. (2010). "Selçuklu ve Osmanlılarda müzikle tedavi yapılan hastaneler". Uludağ Üniversitesi Tıp Fakültesi Dergisi, Volume: 36(1), p. 29-32.

Sezer, F. (2011). "Öfke ve psikolojik belirtiler üzerine müziğin etkisi”. Uluslararası insan bilimleri dergisi, Volume: 8(1), p. 1472-1493.

Silverman, M. J. (2019). "Music therapy and therapeutic alliance in adult mental health: A qualitative investigation". Journal of music therapy, Volume: 56(1), p. 90-116.

Sharma, P. B. (2013). "Musıc: A Tool Of Non Verbal Communication (With Special Reference To Indian MusIC)", International Journal Of Communication And Media Studies (IJCMS) ISSN 2250-0014 Volume: 3(4), p. 1-6.

Somakcı, P. (2003). "Türklerde müzikle tedavi”. Erciyes Üniversitesi Sosyal Bilimler Enstitüsü Dergisi, Volume: 1(15), p.131-140.

Tanyıldızı İ. N. (2012). "Siyasal İletişimde Muzik Kullanımı: 2011 Genel Secim Şarkılarının Secmene Etkisi", Selcuk İletişim, Volume: 7(2), p.97-110.

Tanyıldızı, İ. N. (2020). COVID-19 sürecinde Sağlık İletişiminde Sosyal Medya, Ankara: Iksad Publications.

Thram, D. (2002). "Therapeutic efficacy of music-making: neglected aspect of human experience integral to performance process". Yearbook for traditional music, Volume: 34, p. 129-138.

Tüsside,Tübitak(2020)."DerinlemesineGörüşme" https://tusside.tubitak.gov.tr/tr/yontemlerimiz/DerinlemesineGorusme\#: :text=Yar\%C4\%B1\%2Dyap\%C4\%B1land\%C4\%B1r\%C4\%B1Im\%C4\%B1\%C5\%9F\%20M\%C3\% (20.10.2020).

Ujfalussy, J. (1993). "The Role Of Music And Song In Human Communication”, Acta Neurochirurgica, Volume: 56, p. 6-8.

Vandenberg, F., Berghman, M., Schaap, J. (2020). "The 'lonely raver': music livestreams during COVID-19 as a hotline to collective consciousness?". European Societies, p. 1-12.

Wigram, T., , Elefant, C. (2009). Therapeutic dialogues in music: Nurturing musicality of communication in children with autistic spectrum disorder and Rett syndrome. In S. Malloch \& C. Trevarthen (Eds.), 
Communicative musicality: exploring the basis of human companionship (pp. 423-445). Oxford: Oxford University Press.

Yıldırım, A., Şimşek, H. (2018). Sosyal bilimlerde nitel araştırma yöntemleri. Ankara: Seçkin Publications.

Yıldırım, S. (2020). "Salgınların Sosyal-Psikolojik Görünümü: Covid-19 (Koronavirüs) Pandemi Örneği”. Electronic Turkish Studies, Volume: 15(4), p. 1331-1351. 